\title{
Cost of quality dalam manejeman pendidikan islam
}

\author{
Oleh : Ansori \\ Prodi: MPI VI A \\ Fakultas Agama Islam \\ Universitas Nurul Jadid
}

\begin{abstract}
Abstrak
Dalammenjalankan suatu usaha, baik yang berkaitan dengan produk atau jasa tentu masih diperlukan biaya, yang itu merupakan bagian yang mungkin tidak dapat dipisahkan dari pada kegiatan usaha yang kita jalani, namun selain itu masih saja ada biaya yang seharusnya tidak kita keluarkan, tapi terpaksa kita keluarkan, yaitu biaya mutu.

Biaya mutu merupakan suatu biaya yang andaikan tidak ada biaya itu, maka usaha yang kita jalani akan tetap berjalan namun, tidak akan sesuai dengan apa yang kita harapkan atau yang diharapkan oleh pelanggan.

Biaya mutu digunakan untuk meningkatkan kualitas mutu dari produk yang kita produksi, biaya ini juga masuk dalam hal-hal yang diperlukan untuk mencegah atau memperbaiki kegagalan yang terjadi dalam produk kita.

Dalam segala hal bidang usaha atau produksi jasa, tentunya tentu masih membutuhkan finansial terutama dalam keperluan pokok dalam proses produksi kita, disamping biaya mutu, juga tidak sedikit perusahaan atau suatu instansi hanya terfokuskan pada biaya pokok saja, dan itu merupakan kesalahan yang sangat besar.

Karena akan berdampak pada pemusnahaan peruasahaan itu sendiri, pasalnya, persaingan di era modern ini, konsumen sangat memperhitungkan dan memperhatikan kualitas suatu barang dan jasa, maka tidak pelak, out put yang merupakan hasil produk kita menjadi tidak dilirik oleh masyarakat luas.

Maka ketika itulah nasib perusahaan yang kita pimpin, berada diujung tanduk di ambang kemusnahaan, oleh karena itu, disamping biaya pokok yang dii keluarkan oleh perusaaan kita, biaya kualitas dari produk kita harus lebih di perhatikan.
\end{abstract}

Kata kunci ; Biaya mutu, produk, produksi, perbaikan, kegaagalan.

\section{A. Pendahuluan}


Kalau kita cermati dalam menjalankan usaha produksi baik barang maupun jasa, sebenarnya tidak akan mengeluarkan biaya yang melebihi dari biaya pokok atau biaya yang diperuntukan memproduksi produk kita sesuai dengan keinginan.

Namun karena adanya kerugian yang di timbulkan karena suatu yang tidak sesuai dengan konsumen, maka dikeluarkanlah biaya untuk memperbaiki kerusakan barang yang tidak sesuai, dan menjadikan barang atau jasa menjadi lebih berkualitas dari pada sebelumnya.nah, inilah pokok pembahasan kita, yaitu cost og quality atau biaya kualitas.

Kenapa harus ada biaya kualitas ?, karena dalam situasi pemasaran yang semakin ketat, perusahaan atau suatu instansi berusaha untuk memperoduksi barang atau jasa secara berksinambungan atau kontinue dan diikuti dengan kualitas yang baik. Perusahaan atau suatu instansi yang memproduksi, tanpa memperhatikan kualitas produk, sama saja dengan menghilangkan harapan masa depan, karena tidak bisa dipungkiri, saat ini konsumen semakin kritis dalam memilah dan menentukan produk yang dibeli (jurnal computech dan bisnis,2007;138). 


\section{B. Definisi BiayaKualitas}

\section{Pengertian Biaya}

Sebelum penulis lanjut ke pembahasan inti, alangkah lebih baiknya saya bahas lebih rinci terkait pembahasan kali ini, pertama akan membahas terkaittentang biaya, biaya menurut Charles $\mathrm{T}$ Horngren, George Foster, dan M. Dalar (2000;28) sebagai berikut ; "cost as resource sacrificced or forgone, to achieve a specific objective. It is usually measured as the monetary amount that must be paid to acuere goods and service".

Biaya merupakan suatu kejadian atau peristiwa yang diukur berdasarkan jumlah finansial, yang munkin akan timbul dengan maksud mencapai suatu tujuan tertentu, baik dalam individu, komunitas atau perusahan atau instansi (jurnal analisis pengaruh biaya pencegahan dn biaya penilaian terhadap produk cacat;20016;29).

Dari beberapa definisi yang telah penulis sebutkan, dapat kita tarik benang merah bahwa biaya merupakan suatu pengorbanan dalam bentuk finansial atas aktivitas, produksi perusahaan untuk menghasilkan produksi baik barang atau jasa.

Biaya ini dikeluarkan peruasahaan atau instansi demi keberlangsungan proses produksi dan biasanya memiliki tiga point biaya dasar :

a. Biaya bahan atau material, hal ini mencakup segala hal yang diperlukan untuk bahan-bahan atau peralatan yang digunakan secara langsung dalam menangani kegiatankegiatan produksi.

b. Biaya tenaga kerja langsung, merupakan biaya yang diberikan pada para tenaga kerja yang langsung ditempatkan dan digunakan dalam menangani produksi.

c. Biaya umum, merupakan biaya bahan tidak langsung dan tenaga kerja tidak langsung yaitu bersangkutan dengan produksi yang bukan atau termasuk dalam baiya utama. (Jurnal akutansi dan manajeman 2015;26).

\section{Pengertian kualitas}

Heizer dan render mengatakan bahwa, kualitas merupakan keseluruhan sebuah fitur dan karakteristik suatu produk yang mampu memuaskan kebutuhan,baik yang terlihat atau samar, deaming juga mengatakan bahwa kualitas sebagai kesesuaian 
dengan kebutuhan pasar atau konsumen. (jurnal akutansi manajemen.2005;32)

Dari kedua definisi yang penulis ungkapkan diatas terdapat beberapa kesamaan yaitu bahwa kualitas merupakan suatu upaya perusahaan dalam memenuhi kebutuhan konsumen dan kualitas yang bersifat dinamis.

A joseph M. Juran (dalam hasan baharun;86) lebih kepada mengkalirifikasikan kualitas menjadi trilogi kualitas, dia mengatakan " managing for quality makes eextensive use of three such managirial 1) qyality lanning 2)quality control, 3) quality improvment”.

Penerapan ketiga konsep ; perencanaan kualitas, kendali mutu, dan perbaikan kualitas, mencakup kepada manajemen kualitas menjadi lebih luas dan kompleks. Disamping itu juga membutuhkan keahlian dan dukungan sumber daya dalam pelaksanaannya. (hasan baharun; 86)

\section{Pengertian biaya kualitas}

Biaya kualitas merupakan suatubiaya yang digunakan untuk memperbaiki barang cacat atau memperbaiki jasa yang kurang berkualitas atau tidak begitu sesuai dengan permintaan konsumen.

Hal ini bertujuan agar supaya perusahaan atau instansi dapat bertahan dala persaingan, karena perusaan harus memikirkan tentang peningkatan kualitas dari prosuk yang dihasilakannya, untuk menghasilkan produk atau output yang berkualitas dibutuhkan biaya-biaya yang disebut dengan biaya kualitas.

Biaya kualitas tersebut timbul bisa karena perusahaan beupaya melakukan peningkatan kualitas pada produknya atau timbul karena produknya rendah, oleh karena itu M. Nur mendefinisikan biaya kualitas meruapakan biaya yang dikeluarkan atau munkin akan dikeluarkan karena kualitas produk yang buruk, dengan kata lain biaya kualitas berhubungan dengan penciptaan, perbaika, dan pencegahan kerusakan.

Lebih gampangnya biaya kualitas dapat dikelompokkan menjadi beberapa hal J.M. Juran (dalam jurnal analisis biaya kualitas dalam pencegahan dan penilaian produk,2007;25), yaitu;

a. Biaya Pencegahan

Biaya pencegahan merupakan biaya yang digunakan untuk menjadikan produk suatu peruasaah 
tidak buruk atau mencegah produk agar supaya ketidak sesuai dengan konsumen menjadi hilang.

Biaya-biaya yang termasuk dalam biaya

pencegahan antara lain ;

1) Biaya perencanaan mutu, biaya yang diperuntukkan sebgai perbaikan mutu suatu produk atau biaya-biaya sistem produk dalam rangkan pengembangan mutu.

2) Biaya biaya desain produk, yakni kenaikan biaya terkait dengan membuat desain produk dalam rangka memperbaiki produk.

3) Biaya mendesain proses, merupakan biaya tambahan atau kenaikan biaya dari proses produksi yang baru untuk memperbaiki dan meninjau ulang proses produksi yang ada sehingga produk yang bermutu lebih menjadi berkualitas.

4) Biaya desain tugas, merupakan biaya yang terkait pengembangkan metode kerja baru dan biaya implemetasi dalam bentuk pelatihan para karyawan atau anggota, dlam rangka perbaikan mutu.

5) Biaya kendali proses, yakni biaya kendali utnuk mencapai mutu yang direncanakan dalam pengertian mutu menjadi lebih baik.

6) Biaya koeksi, analisis dan laporan, merupakan biaya-biaya pengumpulan data yang berkaitan dengan perbaikan mutu, termasuk data prduk yang telah rusak.

7) Biaya program perbaikan mutu, biaya terkait memonitor dan memperbaiki kualitas produk.

b. Usaha yang diperlukan membuat item

Lebih lenjutnya biaya mutu dapat dapat dirumuskan sebagai:

1) Biaya yang dikeluarkan dalam untuk menemukan kegagalan sebenarnya, baik di dalam (internally) 
maupun diluar (externally) dan mencegah kegagalan seawal mungkin.

2) Biaya yang dikeluarkan dalam upaya pengamatan, untuk mendapatkan ketidak sesuaian keluaran, Disebut biaya penilaian (Appraisal cost).

3) Biaya sebenarnya darikegagalan itu sendiri dan memeriksanya. Hal ini disebut kegagalan dalam kegagalan Luar (Internal Failure and External Failure Cost).

4) Biaya kegagalan dalam perencanaan atau kegagalan, disebut Biaya Pencegahan (Prevention Cost).

Kalau demikian, biaya mutu merukan semua biaya yang timbul oleh kegiatan usahaatjau kegiatan organisasi atau instansi terhadap keseluruhan layanan yang diharapkan sesuai dengan tuntutan konsumen, Biaya-biaya itu meliputi:

1) Biaya-biaya secara langsung, berkaitan dengan upaya menyediakan barang yang dibeli pelanggan.

2) Biaya yang terkait dengan kegiatan penunjang.

3) Biaya yang tersembunyi seperti peluang yang hilang dari penurunan moral.

\section{Biaya Membuat Produk}

Bila membuat produk (barang atau jasa) diperlukan biaya, apalagi memperbaiki atau mempertahankan mutu.

Biaya kulitas, bukanlah untuk kalkulasi berapa besar biaya untuk memperbaiki atau mempertahankan kulitas produk, tapi bagaimana mengurangi biayauntukmemperbaikiatau mempertahankan mutukalau perlu tanpa mengeluarkan banyak biaya,untuk itu, diperlukan apa pengertian biaya dalam memroduksi.

Dalam membuat produk terdapat 2 (dua) biaya yaitu: Biayayangseharusnya dan Biayayangbisadihindari.

1. Biaya yang seharusnya yaitu:

Biaya yang diperlukan untuk produksi (barang atau jasa) yang bermutu 
2. Biaya yang diperlukan untuk mencapai dan selanjutnya mempertahankan kriteria (standard) yang ditetapkan.

3. Biaya yang bisa dihindari (Avoidable cost $-A C$ ) yaitu:

Biaya karena terjadi sesuatu, diantaranya adalah pekerjaan yang tidak perluatau mengerjakan dengan cara yangsalah, Biaya yang bisa dihindari meliputi:

a) Biaya inspeksi.

b) Biaya akibat produk gagal atau cacat (Failure Cost).

\section{Pentingnya biaya mutu}

Dahulu banyak orang tidak memprinci biaya. Ternyata setelah banyak produk yang tidak disukai konsumen, maka timbul biaya tambahan. dan Sekarang baru di sadari bahw biaya mutu itu penting diketahui dan di kerjakan dengan beberapa alasan:

1. Biaya-biaya tersebut, terkadang berjumlah sangat besar.

2. Biaya itu selain besar, dimana biaya itu terjadi tidak diketahui oleh kebijakan bisnis.

3. Sebagian biaya dikaitkan dengan ke gagalan dan kegiatan penilaian.

Itu berarti penilaian tidak dapat dihindari terhadap sejumlah kegagalan, maka diproduksilah produk yg diterima pelanggan. Keadaan ini membuat pelanggan tidak puas selanjutnya tidak setia.

\section{Biaya-biaya yang Berkaitan dengan Mutu}

Satu dari beberapa cara dalam menemukan biaya mutu adalah dengan mengelompokkan biaya-biaya yang berkaitan dengan biaya mutu, yaitu membedakan antara, biaya pencegahan dengan biaya ketidak sesuaian.

1. Biaya pencegahan

Kegiatan pencegahan dilakukan,agar terhindardari bengkaknya biaya, biaya pencegahan terkati beberapa hal, diataranya:

a. Menyusun prosedur untuk menentukan bagaimana tugas-tugas dilaksanakan.

b. Penyesuaian perlengkapan uji untuk memastikan produk dibuat sesuai dengan spesifikasi. 
c. Pelatihan dan pendidikan para pekerja/pegawai sehingga mereka memahami dan melaksankan tugastugas yang harus dikerjakan.

d. Merawat/memelihara peralatan dan mesin.

e. Merencanakan proses-proses untuk menjamin mutu.

2. Biaya-biaya Ketidak sesuaian

Biaya-biaya ketidak sesuaian adalah semua biaya karena terjadi kegagalan. Bila kegagalan tidak terjadi, maka tidak perlu susah-susah memikirkan biaya.

Biaya-biaya ketidak sesuaian adalah biaya yang timbul karena berbagai kegiatan, diantaranya:

a. Tidak melakukan pekerjaan yang benar.

b. Tidak menyelesikan kegiatan dengan benar sejak awal (pertama kali).

\section{E. Biaya-biaya Penilaian}

Agar dapat mengurangi kesalahan yangsampai kepada pelanggan, perusahaan merupakan bagian sistem untuk menemukan Keslahankesalahan. Biaya untuk menemukan kesalahan di sebut Biaya

Penilaian. Kegiatan yang termasuk kategoribiaya penilaian diantaranya:

1. Meneliti dokumen untuk menetapkan sebelum mendapat persetujuan.

2. Memeriksa barang yng diterima

3. Menguji dan memeriksa baranga setengah jad, antara kegiatan pabrik sampai hasil akhir.

\section{F. Kesimpulan}

Berdasarkan pada penjelasan diatas, dapat kita tarik benang mera terkait dengan biaya mutu, bahwa biaya mutu merupakan bagian intim dari pada proses produksi barang dan jasa.

Mengapa tidak, dalam proses produksi tentuny tidak akan ada kata sempurna, dan pasti kekurangan akan nampak pada saat semua proses telah selesai atau rampung.

Dan biaya mutu merupakan biaya yang dipergunakan untuk menigkatkan mutu dalam suatu prsuk atau jasa, baik dalam meningkat kualitas dalam produk tersebut atau memperbaiki kgagalan yang terjadi saat proses produksi, yang mengakibatkan pada ketidak sesuaian keinginan pelanggan dengan kita. 


\section{Daftar Pustaka}

Baharun, hasan. 2017, (mananemen mutu pendidikan ikhtiar dalam

meningkatkan madrasah melalui pendekatan balance scorecard), akademika pustaka, Tulungagung.

jurnal analisis pengaruh biaya yang di pergunakan untuk pencegahan dan biaya penilaian terhadap produk cacat;2016;29

jurnal computech dan bisnis,2007;138

Jurnal akutansi dan manajeman 2015;26

jurnal akutansi manajemen.2005;32

jurnal analisis biaya kualitas pencegahan dan penilaian produk,2007;25 